\title{
Evaluation of Quality of Some Well Waters Used in Agricultural Irrigation in terms of Plant Nutrition
}

\author{
Cafer Hakan YILMAZ1* \\ Halil AYTOP' \\ Muhammet Rașit SÜNBÜL'1 \\ 'East Mediterranean Transitional Zone Agricultural Research of Institute, Kahramanmaraș, Turkey
}

*Corresponding author e-mail : c_hakanyilmaz@hotmail.com

Received : 25.04.2021

Accepted : 26.07.2021

DOI: $10.21657 /$ topraksu. 927731

\begin{abstract}
In this study, where the suitability of groundwater for irrigation in terms of soil and plants was evaluated, samples were taken from 11 drilling wells used for irrigation in some regions of Kahramanmaraș province. Chemical parameter values such as pH, EC, RSC, SAR, TDS, TH, Na\%, PI, SSP, MR, KR, PS were determined in the assessment of irrigation water quality. According to irrigation water quality criteria, all samples except for two samples were in the medium salt/low sodium water (C2S1) class in terms of EC values. TH values were determined as soft water in all well waters. It was determined that the well waters were not suitable for irrigation in terms of plants and soils, including 3 in terms of Na\%, SSP, MRI and KR values, 2 for Boron, SAR and RSC values, and one each for $\mathrm{pH}$ and PI values. As a result, these wells, which are evaluated problematic for soil and plants in terms of special ionic, salinity and alkalinity, should be used by taking the necessary precautions or should not be used for irrigation.
\end{abstract} SAR

Keywords: Kahramanmaraș, irrigation water quality parameters, plant and soil, salinity and alkalinity,

\section{Tarımsal Sulamada Kullanılan Bazı Kuyu Sularının Kalitelerinin Bitki Besleme Açısından Değerlendirilmesi}

Öz

Yeraltı sularının toprak ve bitkiler açısından sulama için uygunluğunun değerlendirildiği bu çalıșmada, Kahramanmaraș ilinin bazı yörelerinde sulama amacıyla kullanılan 11 adet sondaj kuyusundan örnekler alınmıștır. Sulama suyu kalitesinin değerlendirilmesinde pH, EC, RSC, SAR, TDS, TH, Na\%, PI, SSP, MR, KR, PS gibi kimyasal parametre değerleri belirlenmiștir. Kalite kriterlerine göre, iki örnek dıșında tüm örnekler EC değerleri bakımından orta tuzlu/az sodyumlu su (C2S1) sınıfında yer almıșlardır. TH değerleri, bütün kuyu sularında yumușak su olarak saptanmıștır. \%Na, SSP, MR ve KR değerleri bakımından 3, Bor, SAR ve RSC değerleri için 2, pH ve PI değerleri bakımından ise birer adet olmak üzere kuyu sularının bitki ve toprak açısından sulamaya uygun olmadığı tespit edilmiștir. Sonuç olarak, özel iyonik, tuzluluk ve alkalilik açısından toprak ve bitkiler için problemli olarak değerlendirilen bu kuyular gerekli önlemler alınarak kullanılmalı ya da sulama amaçlı kullanılmamalıdır.

Anahtar Kelimeler: Kahramanmaraș, sulama suyu kalite parametreleri, bitki ve toprak, tuzluluk ve alkalilik, SAR

\section{INTRODUCTION}

The quality of irrigation water is very important in terms of soil fertility and plant nutrition, and it is adversely affected by the mixing of agricultural

(fertilizers and pesticides), industrial and domestic wastewater with underground and surface waters, as it varies depending on the geology of 
its location (Kaykıoğlu and Ekmekyapar, 2005). The amount of cations and anions dissolved in the irrigation water determines the quality of that water and plays an important role directly and indirectly in terms of plant nutrition. It is an indirect effect that salt accumulated in the soil with water increases the osmotic pressure in the soil and causes physiological drought. The fact that elements and chemical compounds such as $\mathrm{B}, \mathrm{Cl}, \mathrm{Na}$ and $\mathrm{HCO}_{3}$ in the irrigation water accumulate in the plant in large amounts and the growth of the plant slow down to the point, which it stops, is also direct effect (Grismer, 1990; Arslan et al., 2007; Jalali and Merrikhpour, 2008; Laz et al., 2018). However, the quality of irrigation water may also vary according to plant types such as halophyte and glycophite plant groups. In determining the quality of irrigation water; Electrical Conductivity (EC), anion $\left(\mathrm{HCO}_{3}\right.$ $\left., \mathrm{CO}_{3}^{-2}, \mathrm{Cl}-, \mathrm{SO}_{4}^{-2}\right)$, cation $\left(\mathrm{Na}^{+}, \mathrm{K}^{+}, \mathrm{Ca}^{+2}, \mathrm{Mg}^{+2}\right)$ content, various parameters [(Sodium Adsorption Rate (SAR), Residual Sodium Carbonate (RSC), Percent Sodium (Na\%), Kelley Ratio (KR), Magnesium Content (MR), Permeability Index (PI), Total Hardness (TH), Potential Salinity (PS)] and graphical methods (Piper, US salinity, Wilcox diagrams, etc.) are used. Many researchers have used SAR, RSC, KI, PI, MR, PS and Na\% values to evaluate the use of surface and groundwater as irrigation water (Arumugam and Elangovan, 2009; Ishaku et al., 2012; Nag and Ghosh, 2013; Wanda et al., 2013; Vincy et al., 2015; Al-Omran et al., 2017). In this study, it was aimed to determine for the suitability of the quality of groundwater taken from 11 wells used for agricultural irrigation in terms of plant nutrition in Onikișubat, Dulkadiroğlu, Göksun and Çağlayancerit regions of Kahramanmaraș in 2019 and 2020.

\section{MATERIAL AND METHOD}

\section{Taking Groundwater Samples from Wells}

In line with the demands of the farmers and water samples from 11 different boreholes used for irrigation in their fields at the locations and dates indicated in Table 1 two samples were taken from each well in line with the criteria determined by Ayyıldız (1990). Water samples were stored in $250 \mathrm{ml}$ sterilized polyethylene plastic bottles at $+4{ }^{\circ} \mathrm{C}$ in the refrigerator until analysis time.
Table 1. Locations and dates of samples taken from wells Çizelge 1. Kuyulardan alınan örneklerin lokasyonları ve tarihler

\begin{tabular}{lccc}
\hline $\begin{array}{c}\text { Well } \\
\text { Number }\end{array}$ & $\begin{array}{c}\text { Taken place } \\
\text { (district-neighborhood) }\end{array}$ & Year & Month \\
\hline 1. Well & Onikișubat - Suçatı & 2019 & April \\
\hline 2. Well & Onikișubat - Kümperli & 2019 & April \\
\hline 3. Well & Dulkadiroğlu - Çınar & 2019 & August \\
\hline 4. Well & Onikișubat - Kılavuzlu & 2019 & September \\
\hline 5. Well & Oniki șubat - Ilıca & 2020 & April \\
\hline 6. Well & Göksun - Tașoluk & 2020 & April \\
\hline 7. Well & C.ağlayancerit - Fatih & 2020 & August \\
\hline 8. Well & Dulkadiroğlu - Çokyașar & 2020 & August \\
\hline 9. Well & Dulkadiroğlu - Osman Bey & 2020 & August \\
\hline 10. Well & Onikișubat - Hacımustafa & 2020 & August \\
\hline 11. Well & Onikișubat - Kürtül & 2020 & August \\
\hline
\end{tabular}

\section{Analysis of Taken Water Samples}

In order to determine the properties of the samples taken, $\mathrm{EC}, \mathrm{pH}, \mathrm{Na}, \mathrm{Ca}, \mathrm{K}, \mathrm{Mg}, \mathrm{CO}_{3}, \mathrm{HCO}_{3}$, $\mathrm{Cl}$ and $\mathrm{SO}_{4}$ analyzes were made. Their $\mathrm{pH}$ was determined by Mettler Toledo Seven Compact $\mathrm{pH}$ meter and electrical conductivity (EC) by Ezdo PL700 AL brand EC meter devices. Taken from wells, concentrations of 4 major elements ( $\mathrm{Na}, \mathrm{K}, \mathrm{Ca}$, Mg) (me $\mathrm{L}^{-1}$ ) and 12 trace elements (Al, B, Cd, $\mathrm{Co}, \mathrm{Cr}, \mathrm{Cu}, \mathrm{Fe}, \mathrm{Mn}, \mathrm{Mo}, \mathrm{Ni}, \mathrm{Pb}$, and $\mathrm{Zn})\left(\mathrm{mg} \mathrm{L}^{-1}\right)$ were measured by Agilent 5100 SVDV brand ICPOES device (APHA, 1989). $\mathrm{CO}_{3}^{-2}, \mathrm{HCO}_{3}-\mathrm{SO}_{4}^{-2}$ and $\mathrm{Cl}^{-}$concentrations were determined by titration method (Richards, 1954). The following 10 equations were used to determine the suitability of the well waters in terms of quality classes and plant nutrition:

Residual sodium carbonate (RSC): $\left(\mathrm{CO}_{3}\right.$ $\left.{ }^{2}+\mathrm{HCO}_{3}^{-2}\right)-\left(\mathrm{Ca}^{+2}+\mathrm{Mg}^{+2}\right)$ (meq $\mathrm{L}^{-1}$ ), (Eaton, 1950; Ragunath, 1987; Aghazadeh and Mogoddam, 2010).

Sodium adsorption rate (SAR): $[\mathrm{Na} / \sqrt{ }((\mathrm{Ca}+\mathrm{Mg}) / 2)]$ (meq $\left.L^{-1}\right)$, (Catrol, 1962; Freeze and Cherry, 1979).

Total amount of dissolved matter (TDS): $0.64^{\star} E C\left(\mathrm{mg} \mathrm{L}^{-1}\right)$, (Catrol, 1962; Freeze and Cherry, 1979)

Total hardness (TH): $2.497^{*} \mathrm{Ca}+4.115^{*} \mathbf{M g}$ (mg L $\mathrm{LCa} \mathrm{CO}_{3}$ ), Sawyer and McCartly, 1967; Todd, 1980). 
Exchangeable sodium percentage /Na\%, ESP): $\left[\mathrm{Na}^{+} /\left(\mathrm{Na}^{+}+\mathrm{K}^{+}+\mathrm{Ca}^{+2}+\mathrm{Mg}^{+2}\right)\right]^{*} 100(\%)$, (Wilcox, 1955; Todd, 1960).

Permeability index (PI): [( $\left.\mathrm{Na}^{+} . \sqrt{ } \mathrm{HCO}_{3}\right) /$ $\left.\left(\mathrm{Na}^{+}+\mathrm{Ca}^{+2}+\mathrm{Mg}^{+2}\right)\right]^{*} 100(\%)$, (Doneen, 1964).

Soluble sodium percentage (SSP): $\left[\left(\mathrm{Na}^{+}+\mathrm{K}^{+}\right)\right.$) $\left.\left(\mathrm{Na}^{+}+\mathrm{K}^{+}+\mathrm{Ca}^{+2}+\mathrm{Mg}^{+2}\right)\right]^{*} 100$ (\%), (Todd, 1960).

Magnesium ratio (MR): $\left[\mathrm{Mg}^{+2}\right]$ $\left.\left(\mathrm{Mg}^{+2}+\mathrm{Ca}^{+2}\right)\right]^{*} 100(\%)$, (Szabolcs and Darab, 1964; Raghunath, 1987).

Kelley ratio (KR): $\mathrm{Na}^{+} /\left(\mathrm{Ca}^{+2}+\mathrm{Mg}^{+2}\right)$ (meq $\left.\mathrm{L}^{-1}\right)$, (Kelley, 1963).

Potential salinity (PS): $\mathrm{Cl}^{-}+1 / 2 \cdot \mathrm{SO}^{-2}\left(\right.$ meq $\left.^{-1}\right)$, (Doneen, 1964).

\section{Statistical Analysis}

Descriptive statistical analyzes of the data obtained as a result of laboratory studies were made using IBM SPSS Statistics 25.0 program.

\section{RESULTS AND DISCUSSION}

\section{Descriptive Statistics of Chemical Parameters of Well Waters}

Descriptive statistical data of chemical analysis of samples uptaken from wells are given in Table 3. The calculated coefficient of variation (CV) values were the highest parameter, RSC (817.42\%), while the lowest parameters were $\mathrm{Cd}(0.00 \%)$, Co (0.00\%), Cu (0.00\%), Ni (0.00\%) and Zn (0.00\%) is. Generally, it shows low variability if $\mathrm{CV}<10 \%$, moderate variability if $10 \%<C V<100 \%$, and high variability when CV> 100\% (Zhou et al., 2012; Ağca, 2014). According to this classification, pH, $\mathrm{Cd}, \mathrm{Co}, \mathrm{Cu}, \mathrm{Ni}$ and $\mathrm{Zn}$ values of waters are low variability, and $\mathrm{RSC}$, Boron, $\mathrm{Na}, \mathrm{K}, \mathrm{Cl}, \mathrm{SO} 4, \mathrm{Al}$, $\mathrm{Cr}, \mathrm{Fe}, \mathrm{Mn}, \mathrm{Pb}, \% \mathrm{Na}, \mathrm{PI}, \mathrm{SSP}, \mathrm{KR}$ and PS values showed high variability, while other parameters also showed moderate variability (Table 3). Low $\mathrm{CV}$ values indicate homogeneous distribution of parameters, while high CV values indicate nonhomogeneous distributions (Ağca, 2014). While the cation sequences were from large to small, $\mathrm{Na}^{+}>\mathrm{Ca}^{+2}>\mathrm{Mg}^{+2}>\mathrm{K}^{+}$, the anion sequences were determined as $\mathrm{HCO}_{3}{ }^{-}>\mathrm{Cl}->\mathrm{SO}_{4}^{-2}$. The sequence in the trace elements was also obtained as $\mathrm{Al}>\mathrm{Fe}>$ $\mathrm{Pb}>\mathrm{Cd}=\mathrm{Co}=\mathrm{Cr}=\mathrm{Cu}=\mathrm{Mn}=\mathrm{Ni}=\mathrm{Zn}$ (Table 3). Piper (1944) diagram was used to classify the types of according to the major anions and cations of the well waters used in this study. According to this; it was determined that wells of 1, 2, 4, 5, 6, 8 and 9th were $\mathrm{Mg}-\mathrm{HCO}_{3}$ type, wells 3 and 7 were Na-Cl type, well of 10th was mixed type and well of 11 th was $\mathrm{Na}-\mathrm{HCO}_{3}$ type waters. Since the mineral content of the water varies according to the rocks it is in contact with and the dissolving conditions affecting these rocks, it is closely related to the interaction also with the bedrock and parent material it passes through (Karataș et al., 2016). Dissolved ions in excessive amounts in irrigation water adversely affect the chemical and physical structure of the soil and the growth of plants. The suitability of groundwater for irrigation in terms of plant nutrition depends on the effect of mineral concentrations on the soil and plants (Ekmekçi et al., 2005). Increased the concentration of dissolved ions in its content increases the electrical conductivity value (EC) and thus the total dissolved matter amount (TDS). TDS amount of water increases depending on natural resource, agricultural, urban, sewage and industrial wastewater (WHO, 2003). Since the hardness $(\mathrm{TH})$ of the water is caused by the dissolved $\mathrm{Ca}^{+2}$ and $\mathrm{Mg}^{+2}$ ions, the excess of these ions has an enhancing effect TDS and EC.

\section{Quality Parameters of Well Water and Suitability for Irrigation}

pH: It affects the heavy metal content, carbonate balance and relative proportion of nitrogen components, thus soil quality and plant growth. In acidic waters, calcium and magnesium cannot be absorbed sufficiently by plants. Alkaline waters provide a better environment for plants to absorb various metals and plant nutrients. However, basic waters are responsible for the accumulation of calcium carbonate, which affects the physical structure of water (Șimșek and Gündüz, 2007). The absence of $\mathrm{CO}_{3}$ in water indicates that $\mathrm{pH}$ is mainly related to $\mathrm{HCO}_{3}$ hydrolysis (Zhou et al., 2012). The $\mathrm{pH}$ of the wells in this study varies between 7.20-9.70 and they are slightly alkaline waters with an average value of 7.83 (Table 3). Ayers and Westcot (1985) stated that the appropriate $\mathrm{pH}$ value for irrigation water is between 6.50-8.40. For this reason, only the third well out of the 11 sampled wells are not suitable for irrigation (Tables 2 and 4).

Electrical conductivity (EC): The EC concentrations of the waters taken from the wells are $345-2100 \mathrm{\mu} \mathrm{cm}^{-1}$, and the average is 740.55 
Table 2. Classification of irrigation water quality criteria

Cizelge 2. Sulama suyu kalite kriterlerinin sınıflaması

\begin{tabular}{|c|c|c|c|c|c|}
\hline Parameter & Range & Water class & Parameter & Range & Water class \\
\hline \multirow{2}{*}{$\mathrm{pH}^{\prime}$} & $6.5-8.4$ & Appropriate & & $<25$ & Class III-Not suitable \\
\hline & & & $\mathrm{PI}(\%)^{9}$ & $25-75$ & Class II-Good \\
\hline \multirow{4}{*}{$\mathrm{EC}\left(\mu \mathrm{mbos} \mathrm{cm}^{-1}\right)^{2}$} & $0-250$ & C1 Slightly saline water & & $>75$ & Class I-Excellent \\
\hline & $250-750$ & C2 Moderately saline water & & & \\
\hline & $750-2250$ & C3 Strongly saline water & & $0-20$ & Excellent \\
\hline & $>2250$ & C4 Very strongly saline water & & $20-40$ & Good \\
\hline \multirow{5}{*}{$\operatorname{RSC}\left(\mathrm{me} \mathrm{L}^{-1}\right)^{3}$} & & & $\operatorname{SSP}(\%)^{8}$ & $40-60$ & Permissible \\
\hline & $<1.24$ & Safe & & $60-80$ & Suspicious \\
\hline & $1.24-2.5$ & May vary depending on the plant & & $>80$ & Not available \\
\hline & $>2.5$ & Not available & & & \\
\hline & & & $\operatorname{MR}(\%)^{10-11}$ & $<50$ & Appropriate \\
\hline \multirow{4}{*}{$S_{A} R^{2}$} & $0-10$ & S1 Less sodium water & & $>50$ & Not available \\
\hline & $10-18$ & S2 Moderately sodium water & & & \\
\hline & $18-26$ & S3 Strongly sodium water & & $<1$ & Appropriate \\
\hline & $>26$ & S4 Very strongly sodium water & $\mathrm{KR}\left(\mathrm{me} \mathrm{L}^{-1}\right)^{12}$ & $1-2$ & Suitable marginally \\
\hline \multirow{5}{*}{$\operatorname{TDS}\left(\mathrm{mg} \mathrm{L}^{-1}\right)^{4-5}$} & & & & $>2$ & Not available \\
\hline & $<1000$ & Fresh water & & & \\
\hline & 1000-10000 & Brackish water & & $<5$ & Excellent \\
\hline & 10000-100000 & Slightly Saline & PS $\left(\mathrm{me} \mathrm{L}^{-1}\right)^{13}$ & 5-10 & From good to harmful \\
\hline & $>100000$ & Very strongly saline water & & $>10$ & Not available \\
\hline \multirow{5}{*}{$\mathrm{TH}\left(\mathrm{mg} \mathrm{L}^{-1} \mathrm{CaCO}_{3}\right)^{6-7}$} & $<75$ & Soft & & $<4$ & Excellent \\
\hline & $75-150$ & Moderately hard & & $4-7$ & Good \\
\hline & $150-300$ & Hard & $\mathrm{Cl}^{-}\left(\mathrm{meL}^{-1}\right)^{14}$ & $7-12$ & Permissible \\
\hline & $>300$ & Strongly hard & & $12-20$ & Suspicious \\
\hline & & & & $>20$ & Not available \\
\hline \multirow{6}{*}{$\% \mathrm{Na}^{8}$} & $<20$ & Excellent & & & \\
\hline & $20-40$ & Good & & $<4$ & Excellent \\
\hline & $40-60$ & Permissible & & $4-7$ & Good \\
\hline & $60-80$ & Suspicious & $\mathrm{SO}_{4}^{-}\left(\mathrm{me} \mathrm{L}^{-1}\right)^{14}$ & $7-12$ & Permissible \\
\hline & $>80$ & Not available & & $12-20$ & Suspicious \\
\hline & & & & $>20$ & Not available \\
\hline
\end{tabular}

\begin{tabular}{|c|c|c|c|}
\hline \multicolumn{4}{|c|}{$\operatorname{Bor}\left(\mathrm{mg} \mathrm{L}^{-1}\right)^{3}$} \\
\hline Sensitive plants & Moderately sensitive plants & Resistant plants & Evaluation \\
\hline $0-0.32$ & $0-0.66$ & $0-0.99$ & None (Very good) \\
\hline $0.33-0.66$ & $0.67-1.32$ & $1.00-1.99$ & Slighly (good) \\
\hline $0.67-0.99$ & $1.33-1.99$ & $2.00-2.99$ & Moderately (Available) \\
\hline $1.01-1.25$ & $2.00-2.50$ & $3.00-3.75$ & Much (Suspicious) \\
\hline$>1.25$ & $>2.50$ & $>3.75$ & Too Much (Unavailable) \\
\hline
\end{tabular}

MS cm $\mathrm{cm}^{-1}$ (Table 3). 1., 2., 3., 4., 6., 7., 8. and 9. (Tables 2 and 4). C3 class waters cannot be used wells are in class C2 (medium salt water), 5., 7., in lands with insufficient drainage. Even if the 10. and 11 . wells are in class C3 (high salt water) drainage is good, salt-resistant plants should be 
selected and special precautions should be taken to control salinity.

Boron: It is an element found in all waters, necessary for plant growth, but toxic at concentrations above the appropriate value. Although $0.2 \mathrm{mg} \mathrm{L}^{-1}$ boron is required in water for some plants, 1-2 $\mathrm{mg} \mathrm{L}^{-1}$ can be toxic (Anonymous, 2020). Boron values in our water samples varied between $0.01-2.90 \mathrm{mg} \mathrm{L}^{-1}$, and average is 0.48 $\mathrm{mg} \mathrm{L}^{-1}$ (Table 3). Accordingly, the 7 th and 11 th wells are not suitable for irrigation for plants sensitive to boron (Tables 2 and 4).

Sodium percentage ( $\mathrm{Na} \%)$ : It is used to determine the suitability of groundwater for agricultural irrigation (Wilcox, 1955). High amounts of $\mathrm{Na}$ in irrigation water are adsorbed by clay particles and replaced by $\mathrm{Mg}$ and Ca ions. The increase the Sodium Adsorption Rate (SAR) in irrigation water, means an increase also the SAR value of the soil saturation extract. As a result of this, the exchangeable sodium percentage (ESP) of the soil increases and the soil shows to tend to sodification (Sağlam and Adiloğlu, 1995). Na\% concentrations of uptaken well waters, It varied between 1.92-95.64\% and its average was determined as $32.60 \%$ (Table 3). Therefore, it has been determined that the 3rd, 7th and 11 th well waters are not suitable for soil and plants according to Todd (1960) (Tables 2 and 4).

Sodium adsorption rate (SAR): Since it measures the danger of alkali/sodium, it is an important parameter that determines the appropriateness of the use of groundwater for irrigation water purpose (Subrahmani et al., 2005). The excess $\mathrm{Na}^{+}$makes the tillage difficult by reducing the permeability of the soil and negatively affects the plant growth (Todd, 1980; Todd and Mays, 2005; Berhe et al., 2015). For well waters SAR values, it was between 0.06-17.14, and its average also determined as 4.30 (Table 3). According to Table 2 , the waters of the 3rd and 7th wells are in S2 class (medium sodium water), the others are in $\mathbf{S 1}$ (low sodium water) class (Table 4). In S1 class water can be used safely for irrigation of almost every type of soil. However, harmful amounts of sodium may accumulate in the bodies of stone fruit trees such as almond and apricot that are too sensitive to sodium. Class S2 waters have high cation exchange

Table 3. Descriptive statistical data of well water parameters $(n=11)$

Çizelge 3. Kuyu suyu parametrelerinin tanımlayıcı istatistiksel verileri (n=11)

\begin{tabular}{lcccccc}
\hline & $\mathrm{n}$ & Minimum & Maximum & Mean & Std. Deviation & Coefficient of variation (CV) \\
\hline $\mathrm{pH}$ & 11 & 7.20 & 9.70 & 7.83 & 0.67 & 8.51 \\
$\mathrm{EC}\left(\mu \mathrm{mbos} \mathrm{cm}{ }^{-1}\right)$ & 11 & 345.00 & 2100 & 740.55 & 507.97 & 68.59 \\
$\mathrm{Bor}\left(\mathrm{mg} \mathrm{L}^{-1}\right)$ & 11 & 0.01 & 2.90 & 0.48 & 0.95 & 198.24 \\
$\mathrm{Na}^{+}\left(\mathrm{meq} \mathrm{L}^{-1}\right)$ & 11 & 0.08 & 21.94 & 4.05 & 6.57 & 162.24 \\
$\mathrm{~K}^{+}\left(\mathrm{meq} \mathrm{L}^{-1}\right)$ & 11 & 0.00 & 0.12 & 0.03 & 0.03 & 112.55 \\
$\mathrm{Ca}^{+2}\left(\mathrm{meq} \mathrm{L}^{-1}\right)$ & 11 & 0.09 & 5.67 & 2.71 & 1.49 & 55.24 \\
$\mathrm{Mg}^{+2}\left(\mathrm{meq} \mathrm{L}^{-1}\right)$ & 11 & 0.16 & 6.70 & 2.43 & 2.19 & 90.42 \\
$\mathrm{HCO}_{3}-\left(\mathrm{meq} \mathrm{L}^{-1}\right)$ & 11 & 2.27 & 9.21 & 5.51 & 2.06 & 37.38 \\
$\mathrm{Cl}\left(\mathrm{meq} \mathrm{L}^{-1}\right)$ & 11 & 0.03 & 19.24 & 2.97 & 5.60 & 188.59 \\
$\mathrm{SO}-{ }_{4}^{-2}\left(\mathrm{meq} \mathrm{L}^{-1}\right)$ & 11 & 0.04 & 3.25 & 0.72 & 0.90 & 124.42 \\
$\mathrm{RSC}\left(\mathrm{meq} \mathrm{L}^{-1}\right)$ & 11 & -5.11 & 6.15 & 0.39 & 3.14 & 817.42 \\
$\mathrm{SAR}$ & 11 & 0.06 & 17.14 & 4.30 & 6.73 & 156.53 \\
$\mathrm{TDS}\left(\mathrm{mg} \mathrm{L}^{-1}\right)$ & 11 & 220.80 & 1344 & 473.95 & 325.10 & 68.59 \\
$\mathrm{TH}\left(\mathrm{mg} \mathrm{L}^{-1} \mathrm{CaCO}_{3}\right)$ & 11 & 0.85 & 35.57 & 16.73 & 11.09 & 66.33 \\
$\% \mathrm{Na}$ & 11 & 1.92 & 95.64 & 32.60 & 38.08 & 116.83 \\
$\mathrm{PI}(\%)$ & 11 & 3.68 & 231.7 & 76.78 & 86.44 & 114.06 \\
$\mathrm{SSP}(\%)$ & 11 & 2.12 & 96.03 & 32.89 & 38.21 & 116.18 \\
$\mathrm{MR}(\%)$ & 11 & 6.46 & 75.67 & 44.60 & 19.10 & 42.83 \\
$\mathrm{KR}\left(\mathrm{meq} \mathrm{L}^{-1}\right)$ & 11 & 0.02 & 24.1 & 3.33 & 7.24 & 217.65 \\
$\mathrm{PS}\left(\mathrm{meq} \mathrm{L}^{-1}\right)$ & 11 & 0.05 & 19.68 & 3.33 & 5.65 & 169.79 \\
\hline
\end{tabular}


capacity (CEC) and can therefore be used in coarse and organic soils with high permeability.

Soluble sodium percentage (SSP): It helps to determine the Na hazard of irrigation water. When the $\mathrm{Na}^{+}$concentration is excess, it is adsorbed by clay particles and replaced by $\mathrm{Ca}^{+2}$ and $\mathrm{Mg}^{+2}$ ions. This change reduces permeability in the soil and causes poor internal drainage (Saleh et al., 1999; Collins and Jenkins, 1996) and can stop plant growth (Joshi et al., 2009). SSP values of the wells studied, it varied between 2.12-96.03\%, and its average was found to be $32.60 \%$ (Table 3). Quality classes, 1., 2., 6., 8., 9. and 10. wells excellent, 4. and 5. wells good but, 3., 7. and 11. wells are not suitable for irrigation (Tables 2 and 4).

Residual sodium carbonate (RSC): It is used to determine the effect of carbonate and bicarbonate in irrigation water on water quality. In soils irrigated for a long time with irrigation waters of which RSC value exceeds $2.5 \mathrm{me} \mathrm{L}^{-1}$, Na accumulation causes salinization and sodification problems in soils over time. The RSC values of groundwater uptaken from the wells were between $-5.11-6.15 \mathrm{me} \mathrm{L}^{-1}$, and its average was also found $0.38 \mathrm{me} \mathrm{L}^{-1}$ by us (Table 3 ). Accordingly, the 5th and 11 th wells are not suitable, the 3rd, 4th and 7th wells differ depending on the plant, the other wells have been determined in the safe class (Tables 2 and 4).

Total amount of dissolved matter (TDS): It is another indication of salinity in water. When there is excessive amount of salt coming from major ions in irrigation water, it affects the osmotic activities of plants and prevents adequate aeration (Obiefuna and Sheriff, 2011). The calculated TDS values of the well waters ranged between 220.80$1344 \mathrm{mg} \mathrm{L}^{-1}$, and its average was also found to be $473.95 \mathrm{mg} \mathrm{L}^{-1}$ (Table 3). According to the class values in Table 2 , it was determined that only the 7th well water is brackish water and the others are in the fresh water class (Table 4).

Total hardness (TH): The hardness of the waters comes from the ions of calcium and

Table 4. Chemical analysis data of well waters

Clizelge 4. Kuyu sularının kimyasal analiz verileri

\begin{tabular}{|c|c|c|c|c|c|c|c|c|c|c|c|}
\hline Parameter & 1. & 2. & 3. & 4. & 5. & 6. & 7. & 8. & 9. & 10. & 11. \\
\hline $\mathrm{pH}$ & 8.00 & 7.49 & 9.70 & 7.92 & 7.20 & 7.55 & 7.68 & 7.55 & 7.91 & 7.40 & 7.71 \\
\hline $\mathrm{EC}\left(\mu \mathrm{mhos} \mathrm{cm}^{-1}\right)$ & 345.00 & 434 & 433 & 490 & 1050 & 388 & 2100 & 580 & 560 & 935 & 831 \\
\hline Boron $\left(\mathrm{mg} \mathrm{L}^{-1}\right)$ & 0.01 & 0.01 & 0.04 & 0.13 & 0.32 & 0.01 & 2.90 & 0.05 & 0.03 & 0.03 & 1.76 \\
\hline $\mathrm{Na}^{+}\left(\mathrm{me} \mathrm{L}^{-1}\right)$ & 0.08 & 0.10 & 5.81 & 2.68 & 3.80 & 0.09 & 21.94 & 0.20 & 0.20 & 0.99 & 8.61 \\
\hline $\mathrm{K}^{+}\left(\mathrm{me} \mathrm{L}^{-1}\right)$ & 0.01 & 0.01 & 0.02 & 0.04 & 0.05 & 0.00 & 0.12 & 0.01 & 0.01 & 0.02 & 0.04 \\
\hline $\mathrm{Ca}^{+2}\left(\mathrm{me} \mathrm{L}^{-1}\right)$ & 2.84 & 2.99 & 0.09 & 2.50 & 4.12 & 3.47 & 1.64 & 2.15 & 3.11 & 5.67 & 1.17 \\
\hline $\mathrm{Mg}^{+2}\left(\mathrm{me} \mathrm{L}^{-1}\right)$ & 1.07 & 2.10 & 0.16 & 1.91 & 1.86 & 0.24 & 1.63 & 6.70 & 4.96 & 5.21 & 0.83 \\
\hline $\mathrm{CO}_{3}^{-2}\left(\mathrm{me} \mathrm{L}^{-1}\right)$ & 0.00 & 0.00 & 0.00 & 0.00 & 0.00 & 0.00 & 0.00 & 0.00 & 0.00 & 0.00 & 0.00 \\
\hline $\mathrm{HCO}_{3}^{-}\left(\mathrm{me} \mathrm{L}^{-1}\right)$ & 3.36 & 4.41 & 2.27 & 6.64 & 9.21 & 3.72 & 5.20 & 6.45 & 5.48 & 5.76 & 8.14 \\
\hline $\mathrm{Cl}^{-}\left(\mathrm{me} \mathrm{L}^{-1}\right)$ & 0.48 & 0.50 & 0.55 & 0.45 & 0.11 & 0.03 & 19.24 & 2.24 & 2.22 & 5.18 & 1.67 \\
\hline $\mathrm{SO}_{4}^{-2}\left(\mathrm{me} \mathrm{L}^{-1}\right)$ & 0.16 & 0.29 & 3.25 & 0.04 & 0.52 & 0.06 & 0.89 & 0.37 & 0.59 & 0.94 & 0.83 \\
\hline RSC (me L-1) & -0.55 & 0.68 & 2.03 & 2.23 & 3.23 & 0.01 & 1.92 & -2.40 & -2.60 & -5.11 & 6.15 \\
\hline SAR & 0.06 & 0.06 & 16.73 & 1.80 & 2.20 & 0.06 & 17.14 & 0.10 & 0.10 & 0.42 & 8.63 \\
\hline $\operatorname{TDS}\left(\mathrm{mg} \mathrm{L}^{-1}\right)$ & 222.80 & 277.76 & 277.12 & 313.60 & 672.00 & 248.32 & 1344.00 & 371.20 & 358.40 & 598.40 & 531.84 \\
\hline $\mathrm{TH}\left(\mathrm{mg} \mathrm{L}^{-1} \mathrm{CaCO}_{3}\right)$ & 11.49 & 16.11 & 0.85 & 14.11 & 17.94 & 9.66 & 10.82 & 32.93 & 28.20 & 35.57 & 6.31 \\
\hline$\% \mathrm{Na}$ & 2.00 & 1.92 & 95.64 & 37.56 & 38.67 & 2.29 & 86.61 & 2.22 & 2.46 & 8.30 & 80.90 \\
\hline $\mathrm{PI}(\%)$ & 3.68 & 4.05 & 144.66 & 97.34 & 117.97 & 4.41 & 198.41 & 5.64 & 5.77 & 19.96 & 231.70 \\
\hline $\operatorname{SSP}(\%)$ & 2.25 & 2.12 & 96.03 & 38.12 & 39.19 & 2.37 & 87.07 & 2.32 & 2.57 & 8.44 & 81.28 \\
\hline MR (\%) & 27.37 & 41.26 & 64.73 & 43.35 & 31.07 & 6.46 & 49.85 & 75.67 & 61.45 & 47.88 & 41.52 \\
\hline $\mathrm{KR}\left(\mathrm{me} \mathrm{L}^{-1}\right)$ & 0.02 & 0.02 & 24.10 & 0.61 & 0.64 & 0.02 & 6.70 & 0.02 & 0.03 & 0.09 & 4.32 \\
\hline$P S\left(m e L^{-1}\right)$ & 0.56 & 0.65 & 2.18 & 0.47 & 0.36 & 0.05 & 19.68 & 2.42 & 2.52 & 5.65 & 2.09 \\
\hline Water class & C2S1 & C2S1 & C2S2 & C2S1 & C3S1 & C2S1 & C3S2 & C2S1 & C2S1 & C3S1 & C3S1 \\
\hline
\end{tabular}


magnesium, which were dissolved in it (Varol et al., 2005; Boysan and Sengörür, 2009). It is measured in German, French, American and British degrees of hardness. The THs of the sampled well waters were found between 0.85-35.57 $\mathrm{mg} \mathrm{L}^{-1} \mathrm{CaCO}_{3}$ and the average was determined as $16.73 \mathrm{mg} \mathrm{L}^{-1}$ $\mathrm{CaCO}_{3}$ by us (Table 3). Hard waters are preferred in terms of irrigation water quality. Because, hard water forms soft soil and soft water forms hard soil (Sağlam and Adiloğlu, 1997). Since the waters of all the wells studied are $<75 \mathrm{mg} \mathrm{L}^{-1} \mathrm{CaCO}_{3}$, they are in the soft water class (Tables 2 and 4). Therefore, continuous use of these waters will cause problems for plants as they will harden the soil over time.

Permeability index (PI): PI value is used to determine the possible effect of water quality on the physical properties of the soil. PI values in the water samples uptaken ranged from 3.68\% to $231.70 \%$ and the average was found to be 72.78\% (Table 3). Accordingly, the 1st, 2nd, 6th, 8th, 9th and 10th wells are not suitable for irrigation for plants (III. Class), and the 3rd, 4th, 5th, 7th and 11 th wells are It has been identified as perfect water (Class I) (Tables 2 and 4).

Magnesium ratio (MR): High $\mathrm{Mg}^{+2}$ ratio in water makes the soil salty and negatively affects plant growth and yield (Joshi et al., 2009; Venugopal et al., 2009). The MR rates of the well waters varied between 6.46-75.67\% and the average was determined as $44.60 \%$ (Table 3). According to these data, except the 3rd, 8th and 9th wells, the others were found to be suitable for irrigation (Table 4).
Kelley ratio (KR): Against the amount of $\mathrm{Na}^{+}$, it is expressed as $\mathrm{Ca}^{+2}$ and $\mathrm{Mg}^{+2}$ ratio. Water with a Kelley ratio of $<1$ is considered suitable for irrigation. The KR values of the examined wells varied between 0.02-24.10 $\mathrm{me} \mathrm{L}^{-1}$, and the average was found to be $3.32 \mathrm{me} \mathrm{L}^{-1}$ (Table 3). According to these values, the $3 \mathrm{rd}, 7$ th and 11 th wells are not suitable for irrigation (Tables 2 and 4).

Potential salinity (PS): Depending on the chlorine and sulfate, it determines the danger of the high amount of salt that will occur. The PS amounts of the well waters uptaken was found between $0.05 \mathrm{me} \mathrm{L}^{-1}$ and $19.68 \mathrm{me} \mathrm{L}^{-1}$ and its average as also $3.33 \mathrm{me} \mathrm{L}^{-1}$ by us (Table 3 ). The potential salinity classes of well waters, the 7th well is not suitable for irrigation, the 10th well varies from good to harmful and the other wells are determined as excellent water. According to the analysis results, it was determined that the waters uptaken from 11 wells are suitable for continuous irrigation in every soil in terms of trace elements such as $\mathrm{Al}, \mathrm{Cd}, \mathrm{Co}, \mathrm{Cr}, \mathrm{Cu}, \mathrm{Fe}$, $\mathrm{Mn}, \mathrm{Ni}, \mathrm{Pb}$ and $\mathrm{Zn}$. Because the determined concentrations of these elements were found to be far below the upper limit values that should be found in irrigation water (Table 5). Since the trace elements cannot accumulate in the soil with irrigation water, it will not be a problem for the plants.

\section{CONCLUSIONS}

In this study, the suitability of groundwater for irrigation in terms of plant nutrition was

Table 5. Trace element tolerance limits in irrigation water and irrigation duration

Çizelge 5. Sulama suyunda iz element tolerans sınırları ve sulama süresi

\begin{tabular}{|c|c|c|c|c|c|c|c|c|c|c|c|c|c|c|}
\hline & & $\begin{array}{c}1 . \\
\text { Well }\end{array}$ & $\begin{array}{c}2 . \\
\text { Well }\end{array}$ & $\begin{array}{c}3 . \\
\text { Well }\end{array}$ & $\begin{array}{c}4 . \\
\text { Well }\end{array}$ & $\begin{array}{c}5 . \\
\text { Well }\end{array}$ & $\begin{array}{c}6 . \\
\text { Well }\end{array}$ & $\begin{array}{c}7 . \\
\text { Well }\end{array}$ & $\begin{array}{c}8 . \\
\text { Well }\end{array}$ & $\begin{array}{c}9 . \\
\text { Well }\end{array}$ & $\begin{array}{c}10 . \\
\text { Well }\end{array}$ & $\begin{array}{c}11 . \\
\text { Well }\end{array}$ & $\begin{array}{c}\text { Continuous for } \\
\text { every soil (mg } \\
\mathrm{L}^{-1} \text { ) }\end{array}$ & $\begin{array}{l}r \text { Short term in } \\
\text { fine textured } \\
\text { soils }\left(\mathrm{mg} \mathrm{L}^{-1}\right)\end{array}$ \\
\hline Al & & 0.01 & 0.01 & 0.02 & 0.01 & 0.32 & 0.03 & 0.00 & 0.00 & 0.00 & 0.00 & 0.02 & 1.00 & 20.00 \\
\hline $\mathrm{Cd}$ & & 0.000 & 0.000 & 0.000 & 0.001 & 0.002 & 0.000 & 0.001 & 0.001 & 0.001 & 0.001 & 0.001 & 0.005 & 0.05 \\
\hline Co & & 0.00 & 0.00 & 0.00 & 0.00 & 0.00 & 0.00 & 0.00 & 0.00 & 0.00 & 0.00 & 0.00 & 0.20 & 10.00 \\
\hline $\mathrm{Cr}$ & $\bar{\sigma}$ & 0.00 & 0.00 & 0.00 & 0.00 & 0.00 & 0.00 & 0.01 & 0.01 & 0.03 & 0.00 & 0.00 & 5.00 & 20.00 \\
\hline $\mathrm{Cu}$ & $\stackrel{\underline{\sigma}}{\sigma}$ & 0.00 & 0.00 & 0.00 & 0.00 & 0.00 & 0.00 & 0.00 & 0.00 & 0.00 & 0.00 & 0.00 & 0.20 & 5.00 \\
\hline $\mathrm{Fe}$ & $\underline{\xi}$ & 0.00 & 0.00 & 0.01 & 0.01 & 0.26 & 0.01 & 0.01 & 0.01 & 0.01 & 0.01 & 0.01 & 2.00 & 5.00 \\
\hline $\mathrm{Mn}$ & & 0.00 & 0.00 & 0.00 & 0.00 & 0.01 & 0.00 & 0.00 & 0.00 & 0.00 & 0.00 & 0.00 & 2.00 & 20.00 \\
\hline $\mathrm{Ni}$ & & 0.00 & 0.00 & 0.00 & 0.00 & 0.00 & 0.00 & 0.01 & 0.00 & 0.00 & 0.00 & 0.00 & 0.50 & 2.00 \\
\hline $\mathrm{Pb}$ & & 0.00 & 0.00 & 0.12 & 0.01 & 0.01 & 0.00 & 0.01 & 0.03 & 0.01 & 0.02 & 0.01 & 5.00 & 20.00 \\
\hline Zn & & 0.00 & 0.00 & 0.00 & 0.00 & 0.00 & 0.01 & 0.00 & 0.00 & 0.00 & 0.00 & 0.00 & 5.00 & 10.00 \\
\hline
\end{tabular}


evaluated, belonging to 11 different wells used in Kahramanmaraș. In determining the use of well waters as irrigation water, evaluations were made using chemical parameters such as pH, EC, TDS, SAR, \% Na, RSC, SSP, MR, KI, PI, PS, TH. Accordingly, 5 out of 11 wells showed low variability, 8 of them moderate and 17 of them high variability. From this situation, it is understood that the waters have a partially homogeneous distribution (in 5 wells). In terms of $\mathrm{pH}$, it was determined that all well waters except well number 3 are suitable for irrigation in terms of plant nutrition and soil fertility. In terms of EC values, wells 5 and 7 are respectively in strongly saline/low sodium water (C3S1) and strongly saline/moderately sodium water (C3S2) class. Since C3S1 type waters is not suitable as irrigation water, salt-resistant plants should be selected, regular washing and special soil cultivation programs should be applied. Since C3S2 type waters are not suitable for irrigation, salt-resistant plants should be chosen and they should be used in coarse-textured or organic soils, rich in gypsum with good permeability. Other wells are C2S1 type waters (moderately saline/ low sodium water) and can be used for all plants. It was determined that the 7th and 11 th wells were not suitable for irrigation for Boron sensitive plants. Except for the 7th well, the TDS values of other 10 wells were classified as fresh water. TH values were determined as soft water in all well waters. In terms of Na\% and SSP values, 8 wells other than the 3rd, 7th and 11 th wells were found to be in the appropriate class for soil and plants. According to the SAR values of the well waters, 9 wells except the 3rd and 7th wells are low sodium water (S1). In terms of PI values, 1st, 2nd, 6th, 8th, 9.ve 10th wells are not suitable for irrigation for plants (III. class), 3rd, 4th, 5th, 7.ve 11 th wells are excellent waters in feature (I. Class). According to the RSC values, the wells other than the 5th and 11 th wells, according to the MR values the wells other than the 3rd, 8th and 9th wells, according to the KR values, the wells other than the 3rd, 7th and 11 th wells and according to PS values the wells other than the 7th well have been found suitable for irrigation. In the evaluations made, determined as problematic for soil and plants in terms of special ion, salinity and alkalinity, and the well waters given its numbers above should be used by taking the necessary precautions or not used for irrigation.

\section{ACKNOWLEDGMENTS}

We would like to thank them for giving us the opportunity to do this study with the groundwater samples we take from their wells in line with our farmers' demands.

\section{REFERENCES}

Aghazadeh N, Mogaddam AA (2011). Investigation of hydrochemical characteristics of groundwater in the Harzandat aquifer, Northwest of Iran. Environmental Monitoring and Assessment 176 (1-4): 183-195, doi. org/10.1007/s10661-010-1575-4.

Ağca N (2014). Spatial variability of groundwater quality and its suitability for drinking and irrigation in the Amik Plain (South Turkey). Environmental Earth Science 72: 411 15-4130, doi: 10.1007/s12665-014-3305-7

Al-Omran AM, Aly AA, Al-Wabel MI, Al-Shayaa MS, Sallam AS, Nadeem ME (2017). Geostatistical methods in evaluating spatial variability of groundwater quality in Al-Kharj Region, Saudi Arabia. Applied Water Science 7 (7): 4013-4023, doi: 10.1007/s13201-017-0552-2.

Anonymous (2020). Ankara Üniversitesi Açık Ders Malzemeleri. Kullanılabilir: https://acikders.ankara.edu.tr/ course/view.php?id=212\#section-5, (Erișim tarihi: 10.03.2020).

APHA (1989). Standard methods for the examination of water, sewage, and waste water, 17th Ed. American Public Health Association, New York, p. 1550.

Arslan H, Güler M, Cemek B, Demir Y (2007). Bafra Ovası yeraltı suyu kalitesinin sulama açısından değerlendirilmesi. Tekirdağ Ziraat Fakültesi Dergisi, 4(2): 219-226.

Arumugam K, Elangovan K (2009). Hydrochemical characteristics and groundwater quality assessment in Tirupur Region, Coimbatore District, Tamil Nadu, India. Environmental Geology 58: 1509-1520, doi.org/10.1007/ s00254-008-1652-y.

Ayers RS, Westcot DW (1989). Water quality for agriculture (irrigation and drainage paper). Food and Agriculture Organization of the United Nations. Rome.

Ayyıldız M (1983). Sulama suyu kalitesi ve tuzluluk problemleri. A.Ü. Ziraat Fak. Yayınları, Yayın No: 879, Kitap No: 244, Ankara.

Berhe BA, Çelik M, Dokuz UE (2015). Kütahya Ovası́ndaki yüzey ve yeraltı sularının sulama suyu kalitesi açısından incelenmesi, Türkiye. MTA Dergisi 150: 147-163

Boysan F, Șengörür B (2009). Su sertliğinin insan sağlığı için önemi. Sakarya Üniversitesi Fen Bilimleri Dergisi 13 (1): 7-10.

Catrol D (1962). Rain water as a chemical agent of geological process: A view USGS. Water Supply, 1533: 18-20.

Collins R, Jenkins A (1996). The impact of agricultural land use on stream chemistry in the middle hills of the Himalayas, Nepal. Journal of Hydrology 185: 71-86, doi. org/10.1016/0022-1694/95)03008-5.

Doneen LD (1962). The influence of crop and soil on percolating water. Proceedings of the Biennial Conference on Groundwater Recharge, 156-163. 
Doneen LD (1964). Notes on water quality in agriculture. Published as a water science and engineering, paper 4001 Department of Water Science and Engineering University of California, Davis.

Eaton FM (1950). Significance of carbonates in irrigation waters. Soil Science 69: 123-133.

Ekmekçi E, Apan M, Kara T (2005). Tuzluluğun bitk gelișimine etkisi. Ondokuz Mayıs Üniversitesi Ziraat Fakültesi Dergisi 20 (3): 118-125.

Freeze RA, Cherry JA (1979). Groundwater. Prentice Hall, New Jersey, 604 p.

Grismer ME (1990). Leaching fraction, soil salinity and drainage efficiency. California Agriculture, 44 (6): 24-26.

Ishaku JM, Ahmed AS, Abubakar MA (2012). Assessment of groundwater quality using water quality index and GIS in Jada, Northeastern Nigeria. International Research Journal of Geology and Mining (IRJGM) 2 (3): 54-61.

Jalali M, Merrikhpour $H$ (2008). Effects of poor quality irrigation waters on the nutrient leaching and groundwater quality from sandy soil. Environmental Geology, 53: 1289-1298.

Joshi DM, Kumar A, Agrawal N (2009). Assessment of the irrigation water quality of River Ganga in Haridwar District India. Journal of Chemistry 2 (2): 285-292.

Karataș A, Sungur S, Yılmaz $\vee(2016)$. Physico-chemical features of mineral waters found in Hatay ophiolites and their relationships with fault characteristics. Turkish Studies 11: 665-684

Kaykığlu G, Ekmekyapar F (2005). Ergene havzasında endüstriyel ișlem suyu olarak kullanılan yeraltı sularının özellikleri üzerine bir araștırma. Trakya Ünversitesi Fen Bilimleri Dergisi, 6 (1): 85-91.

Kelley WP (1963). Use of saline irrigation water. Soi Science 95(6): 385-391.

Laz B, Babur E, Akpınar DM, Avgın SS (2018). Kahramanmaraș-Elmalar yeșil kușak Ek-3 plantasyon sahasında görülen biyotik ve abiyotik zararlıların tespiti. KSÜ Tarım ve Doğa Dergisi, 21 (6): 926-935.

Nag SK, Ghosh P (2013). Variation in groundwater levels and water quality in Chhatna Block, Bankura district, West Bengal-AGIS approach. Journal of Geological Society of India, 81: 261-280.

Piper AM (1944). Graphic procedure in the geochemical interpretation of water analyses. Transactions American Geophysical Union, 25(6): 914-928.

Raghunath HM (1987). Groundwater (2nd ed.), Wiley Eastern Ltd, New Delhi, p. 563.

Richards LA (1954). Diagnosis and improvement of saline and alkali soils. Agricultural Handbook 60, USDA \& IBH Publishing Company Limited, New Delhi, India, pp. 98- 99.

Sağlam MT, Adiloğlu A (1997). Su kalitesi (genișletilmiș 2. baskı). Trakya Üniv. Tekirdağ Ziraat Fakültesi, Yayın no: 230, Ders Kitabı No: 27, Tekirdağ.

Saleh A, Al-Ruwaih F, Shehata M (1999). Hydrogeochemical processes operating within the main aquifers of Kuwait. Journal of Arid Environments 42 (3): 195-209.
Sawyer GN, McMcartly DL (1967). Chemistry of sanitary engineers. (2nd ed.), McGraw Hill, New York, p. 518.

Szabolcs I, Darab C (1964). The influence of irrigation water of high sodium carbonate content of soils. In: Szabolics I (ed) Proceedings of 8th International Congress Soil Science Sodics Soils ISSS, Trans., II, 802-812.

Subrahmani T, Elango L, Damodarswamy SR (2005). Groundwater quality and its suitability for drinking and agricultural use in Chithar River Basin, Tamil Nadu, India. Environmental Geology 47: 1099-1110, doi:10.1007/ s00254-005-1243-0.

Șimsek C, Gündüz O (2007). IWO index: A GIS-integrated technique to assess irrigation water quality. Environmental Monitoring and Assessment 128: 277-300, doi: 10.1007/ s10661-006-9312-8.

Șimșek G, Çanlı M, Karadavut U, Yazıcı ME, Soğancı K (2017). Sulama yapılan alanların bazı su parametreleri açısından ayırma (discriminant) analizi kullanılarak incelenmesi. Türk Tarım ve Doğa Bilimleri Dergisi 4 (3): 339-346.

Todd DK (1960). Salt-water intrusion of coastal aquifers in the United States. International Association Scientific Hydrology, Gentbrugge Belgium, 52: 452-461.

Todd DK (1980). Groundwater Hydrology (2nd ed.). John Wiley and Sons, 535p.

Todd DK, Mays LW (2005). Groundwater hydrology (3rd ed.), Wiley, Hoboken, p. 656.

Tuncay H (1986). Suların kalite sınıfları ve analiz yöntemleri. E.Ü. Ziraat Fak. Ders Notları, Bornova, İzmir.

Tüzüner A (1990). Toprak ve su analiz laboratuvarları el kitabı. Tarım Orman ve Köy İșleri Bakanlığı. Köy Hizmetleri Genel Müdürlüğü, Ankara.

Varol F, Bellitürk K, Sağlam MT (2005). Tekirdağ ili sulama sularının Özellikleri. Tarım Bilimleri Dergisi 11: 4, doi: 10.1501/ Tarimbil_0000000554.

Vincy MV, Brilliant R, Pradeepkumar AP (2015). Hydrochemical characterization and quality assessment of groundwater for drinking and irrigation purposes: A case study of Meenachil River Basin, Western Ghats, Kerala, India. Environmental Monitoring and Assessment 187: 4217, doi: 10.1007/s10661-014-4217-4.

Wanda EMM, Gulula LC, Phiri A (2013). Hydrochemical assessment of groundwater used for irrigation in Rumphi and Karonga districts, Northern Malawi. Physics and Chemistry of the Earth 66: 51-59, doi: 10.1016/j. pce.2013.09.001.

Venugopal T, Giridharan L, Jayaprakash M, Periakali $P$ (2009). Environmental impact assessment and seasonal variation study of the groundwater in the Vicinity of River Adyar, Chennai, India. Environmental Monitoring and Assessment 149: 81-97.

Wilcox LV (1955). Classification and use of irrigation waters. USDA Circular No: 969, p. 19.

WHO (2003). Total dissolved solids in drinking-water. World Health Organization Guidelines for drinking-water quality, Geneva. 
Zhou Z, Zhang G, Yan M, Wang J (2012). Spatial variability of the shallow groundwater level and its chemistry characteristics in the Low Plain Around the Bohai Sea, North China. Environmental Monitoring and Assessment 184: 36973710 .

$103 \mid$ 